\title{
Description of a new species of Toumeyella Cockerell (Hemiptera, Coccidae) from Mexico, with a taxonomic key to Mexican species
}

\author{
Takumasa Kondo ${ }^{1} \&$ Giuseppina Pellizzari²
}

\begin{abstract}
${ }^{1}$ Corporación Colombiana de Investigación Agropecuaria, Corpoica, C.I. Palmira, Valle, Colombia. tkondo@corpoica.org.co
${ }^{2}$ Dipartimento di Agronomia Ambientale e Produzioni Vegetali, Università di Padova, Entomologia, Viale dell’Università 16, 35020 Legnaro, Italy. giuseppina.pellizzari@unipd.it
\end{abstract}

\begin{abstract}
Description of a new species of Toumeyella Cockerell (Hemiptera, Coccidae) from Mexico, with a taxonomic key to Mexican species. A new species of soft scale insect from Mexico, Toumeyella fontanai Kondo \& Pellizzari sp. nov. is described and illustrated. A taxonomic key to the species of scale insects of the genus Toumeyella Cockerell known in Mexico is provided.
\end{abstract}

KEYWORDS. Acacia; coccid; soft scales; Toumeyella fontanai.

RESUMO. Descrição de uma nova espécie de Toumeyella Cockerell (Hemiptera, Coccidae) do México e chave do gênero para as espécies mexicanas. Uma nova espécie de coccídeo do México, Toumeyella fontanai Kondo \& Pellizzari sp. nov., é descrita e ilustrada. Uma chave taxonômica para separar as espécies de cochonilhas do gênero Toumeyella Cockerell que ocorrem no México é fornecida.

PALAVRAS-CHAVE. Acacia; coccídeo; cochonilha; Toumeyella fontanai.

According to the scale insects database ScaleNet (BenDov et al. 2010), currently there are 14 species of soft scale insects included in the genus Toumeyella Cockerell, which are distributed in Brazil (2 spp.), Cuba (1 sp.), Mexico (4 spp.) and the United States (9 spp.).

The four species of Toumeyella hitherto recorded from Mexico are: T. erythrinae Kondo \& Williams, 2003 (Fig. 1A), T. mirabilis (Cockerell, 1895) (Fig. 1B), T. parvicornis (Cockerell, 1897) (Figs 1E \& F) and T. sallei (Signoret, 1873) (no available photos).

Signoret (1873) described T. sallei based on a specimen sent to him from Mexico. The original description in French by Signoret was translated (Kondo \& Williams 2004) as follows: "A species of monstrous size, which was collected in Mexico on an undetermined plant, and donated by M. Sallé. Its size is $2 \mathrm{~cm}$ long by $1.5 \mathrm{~cm}$ wide and $0.5 \mathrm{~cm}$ high. The insect is brownish with some pale shading, a bit yellow. It is rugose on the sides". These authors slide-mounted the large, pinned holotype specimen of Neolecanium sallei Signoret, redescribed and illustrated it based on cuticular morphology and transferred it from the genus Neolecanium Parrott to Toumeyella which they considered to be a senior synonym (Kondo \& Williams 2004). The host of T. sallei is unknown.

The erythrina scale, Toumeyella erythrinae, is also a large species, which can grow up to $2.1 \mathrm{~cm}$ long and $2.0 \mathrm{~cm}$ wide, is a pest of Erythrina coralloides (Fabaceae), a common street tree in Mexico City, and was described by Kondo and Williams (2003) based on the adult female and first-instar nymph. The biology and damage caused by T. erythrinae was summarized by Kondo and Williams (2003).
Cockerell (1895) briefly described the Mesquite scale, Toumeyella mirabilis from specimens collected in Tucson (Arizona, USA), off Prosopis juliflora var. glandulosa (Fabaceae). Several years later, Ferris (1921) and Ferris \& Kelly (1923) listed this species as present in some Mexican localities (Aguascalientes, Baja California Norte, Baja California Sur). Toumeyella mirabilis was redescribed by Hodgson (1994) based on non type-material collected in Arizona and Texas off Prosopis sp. and Xanthocephalum (Asteraceae).

The pine tortoise scale, Toumeyella parvicornis is a well known species, redescribed on a modern basis by Williams \& Kosztarab (1972). It is associated with Pinaceae and is widely distributed, from Canada to Mexico (Williams \& Kondo 2008). Toumeyella parvicornis has both a bark (Fig. 1E) and leaf form (Fig. 1F) (Hamon \& Williams 1984; Williams \& Kondo 2008) and occasionally it is damaging to pine seedlings and saplings (Hamon \& Williams 1984).

On December 8, 2006, near Tlacotepec city (state of Puebla, Mexico), a single soft scale insect specimen was collected on a wild Acacia sp. (Fabaceae) growing in the maquis ("matorral" in Spanish) by the entomologist Paolo Fontana. The host plant was also infested by Coccus longulus (Douglas) (Fig. 1C \& D). The insect was sent to the second author who slide-mounted the insect and recognized it as an undescribed species belonging to the genus Toumeyella. The specimen was later sent to the first author who confirmed its novelty, and prepared a description of the species. Here we describe the new species based on the adult female. Although we were reluctant to describe a new species based on a single specimen, the combination of morphological features of the 
discovered insect justified the description of a new species, however, there is a risk that the specimen described here may not be representative of the species.

\section{MATERIAL AND METHODS}

The specimen was slide-mounted following the procedure described by Ben-Dov \& Hodgson (1997). The terminology of morphological features follows mostly that of Hodgson (1994) and the illustration of the adult female (Fig. 2) shows the dorsum on the left and the venter on the right with enlargements of important features around the margin.

Specimen depository. CNIN: Instituto de Biología, Departamento de Zoología, Universidad Autónoma de México, Apartado Postal 70-153, Mexico city, D.F. 04510, Mexico.

\section{RESULTS AND DISCUSSION}

\section{Genus Toumeyella Cockerell}

Type-species: Lecanium (Toumeyella) mirabile Cockerell, 1895: 2.

Diagnosis (Adapted from Williams \& Kosztarab 1972). Body of adult female convex to globular, often irregular in outline, naked or with thin glassy test. Dorsum. Derm heavily sclerotized at maturity. Dorsal tubercles absent. Unilocular or bilocular microducts present; aggregations of pores rarely present. Preopercular pores present, large. Anal plates with varying number of apical, subapical and fringe setae. Hypopygial setae present. Anal ring usually with 10 (rarely 12-14) setae. Margin. Marginal setae slender or stout, pointed or blunt but never frayed. Stigmatic setae present, 3 per stigmatic area, or completely absent. Venter. Antenna and legs greatly reduced. Legs without tibio-tarsal sclerotization. Quinquelocular pores usually present in spiracular furrows and also in vulvar and abdominal region. Tubular ducts confined to perivulvar area.

Taxonomic key to the Toumeyella species of Mexico based on the adult female (characters taken from Williams \& Kosztarab 1972; Kondo \& Williams 2003, 2004; Hodgson 1994)

1. With aggregations of $2-15$ fused bilocular pores scattered over dorsum Toumeyella parvicornis (Cockerell)

1'. Without such aggregations of bilocular pores scattered over dorsum

2. Width of posterior spiracular peritreme about same length or longer than length of anal plates, anal ring with 12-14 setae ............ Toumeyella erythrinae Kondo \& Williams

2'. Width of posterior spiracular peritreme shorter than length of anal plates, anal ring with 10 setae .. 3

3. Antennae 7 segmented. Spiracular pore bands narrowing from each spiracle to spiracular cleft, less than 5 pores wide near body margin

Toumeyella fontanai Kondo \& Pellizzari, sp. nov.
3'. Antennae usually 6 segmented. Spiracular pore bands widening broadly from each spiracle to spiracular cleft, about $30-50$ pores wide near body margin

4. Spiracular clefts present, well developed; spiracular setae well differentiated from marginal setae, numbering 3 per spiracular cleft Toumeyella sallei (Signoret)

4'. Spiracular clefts absent; spiracular setae absent or not differentiated from marginal setae

Toumeyella mirabilis (Cockerell)

\section{Toumeyella fontanai Kondo \& Pellizzari, sp. nov.}

Proposed common name: English: Fontana's soft scale. Spanish: Escama blanda de Fontana.

Material studied. Holotype: adult female (CNIN). Type-locality: Mexico, state of Puebla, Cacaloapan, $11 \mathrm{~km} \mathrm{SW}$ Tlacotepec city, $1890 \mathrm{~m}$ asl, $18^{\circ} 36^{\prime} 23.1$ 'N, 097³5'55.3”W, 8.xii.2006, coll. P. Fontana, ex Acacia sp.

Description. Adult female (Figs. 1C, D \& 2).

Unmounted material (Fig. 1C \& D). Body round in shape, posterior end elevated, $2.8 \mathrm{~mm}$ at highest point. Derm grayish brown in color, with a pinkish cream narrow submarginal band; dorsum with a pinkish cream colored V-shaped elevation, with outer sides of elevation deeply depressed. Insect in life $5.2 \mathrm{~mm}$ long and $5.2 \mathrm{~mm}$ wide.

Mounted material. (Fig. 2) Body outline oval, body 5.7 $\mathrm{mm}$ long, $5.8 \mathrm{~mm}$ wide.

Dorsum. Derm membranous. Dorsal setae bluntly to sharply spinose, straight or slightly curved, each 20-33 $\mu \mathrm{m}$ long, scattered evenly. Dorsal microducts each about $5 \mu \mathrm{m}$ wide, with a long terminal filament, evenly scattered. Simple pores each 5-6 $\mu \mathrm{m}$ wide, evenly scattered. Preopercular pores numerous, present in a rather dense mid-dorsal line extending from area anterior to anal plates to head near margin, and also scattered throughout most of dorsum, but absent from margin and submargins, each pore $7.5-13.0 \mu \mathrm{m}$ wide. Dorsal tubular ducts, dorsal tubercles and pocket-like sclerotizations absent. Anal plates together quadrate, with rounded angles, plates located about $1 / 4$ of body length from posterior margin, each plate 250-255 $\mu \mathrm{m}$ long, 130-135 $\mu \mathrm{m}$ wide, anterolateral margin 150-155 $\mu \mathrm{m}$ long, posterolateral margin 220-225 $\mu \mathrm{m}$ long, with 3 apical setae on posterior inner margin, plus 1 pair of long fringe setae, about 5 ventral subapical setae and numerous hypopygial setae. Anal ring with 10 setae (not illustrated). A sclerotic area present around anal plates.

Margin. Marginal setae bluntly to sharply spinose, straight to slightly bent, each $25-43 \mu \mathrm{m}$ long, arranged in a single irregular row, with $8-10$ on each side between anterior and posterior stigmatic areas. Stigmatic clefts shallow, with 3 stigmatic setae per stigmatic area, median seta longest, 47-55 $\mu \mathrm{m}$ long, lateral setae each 14-28 $\mu \mathrm{m}$ long. Eyes not detected.

Venter. Derm entirely membranous. Pregenital disc-pores each 7-9 $\mu \mathrm{m}$ wide, mostly with 5 loculi (range 3-6), present around vulvar area and in a submedial line between vulva and posterior spiracle on each side. Spiracular disc-pores mostly 

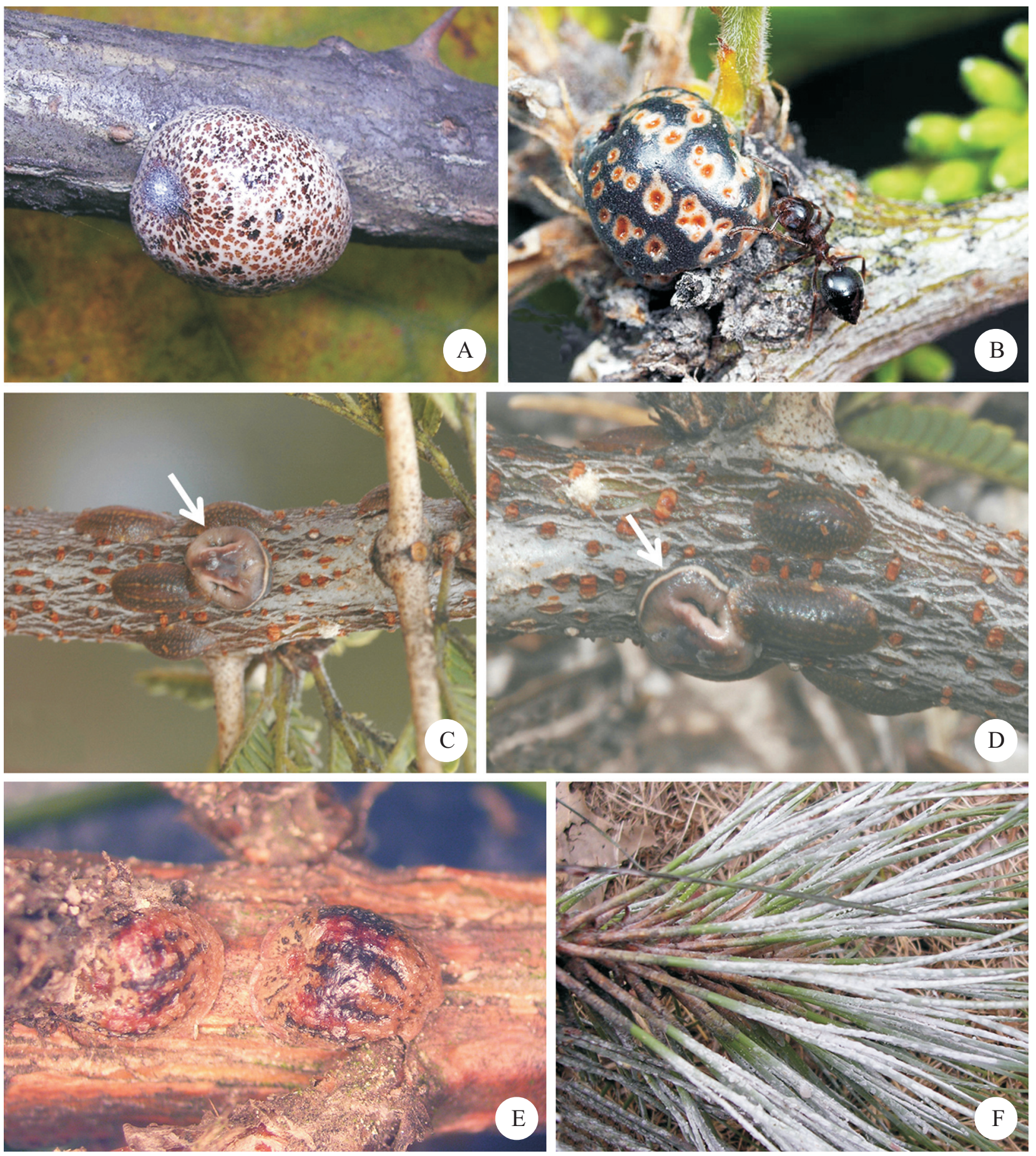

Fig. 1. (A) Toumeyella erythrinae Kondo \& Williams on Erythrina collaroides (Mexico City, Mexico). (B) Toumeyella mirabilis (Cockerell) on Prosopis juliflora (Arizona, USA). (C) Toumeyella fontanai Kondo \& Pellizzari (see arrow) surrounded by Coccus longulus (Douglas) on twig of Acacia tree. (D) Side view of $T$. fontanai (see arrow) showing a large side depression. Notice grayish-pink submarginal band. (E-F) Toumeyella parvicornis (Cockerell) (Alabama, USA): (E) bark form, (F) leaf form. Photos 1A, E, F by T. Kondo, 1B by Alex Wild, and 1C \& D by P. Fontana.

with 5 loculi (range 3-8), each pore 6.3-9.5 $\mu$ m wide, present in a broad band as wide as peritremes, extending laterally from each spiracle to body margin, pore band narrowing near margins. Ventral microducts scattered evenly throughout, each about $5 \mu \mathrm{m}$ wide. Ventral tubular ducts present around vulvar region, each tubular duct with an inner filament ending in a small gland. Ventral setae slender, straight or slightly bent, each 15-28 $\mu \mathrm{m}$ long; with 3 pairs of long median setae, each $47-65 \mu \mathrm{m}$ long on pregenital segments and 2 pairs of interantennal setae. Spiracles well developed, large, anterior spiracular peritremes each $175 \mu \mathrm{m}$ wide, posterior peritremes each $195 \mu \mathrm{m}$ wide. Legs greatly reduced, but most segments 


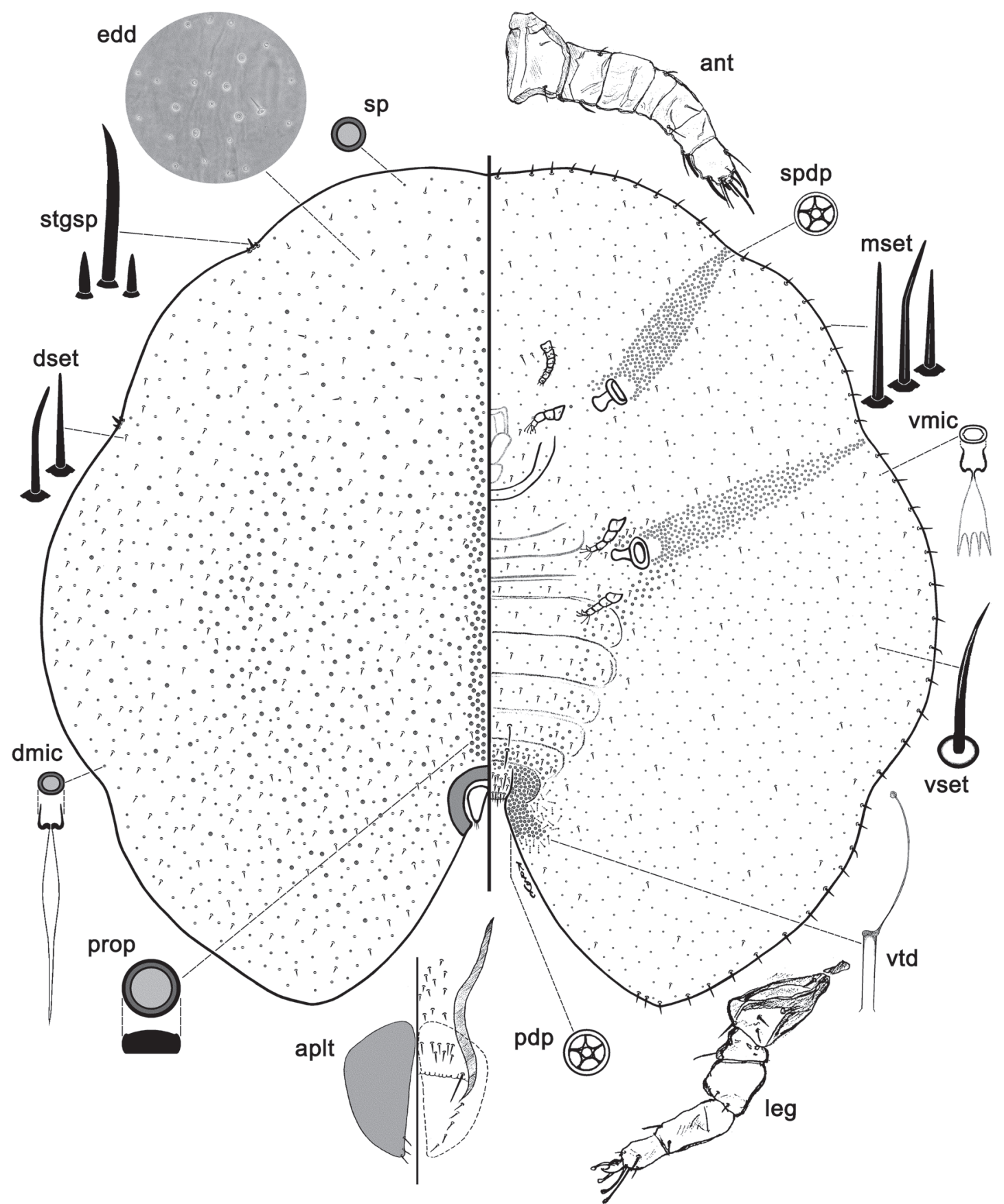

Fig. 2. Toumeyella fontanai Kondo \& Pellizzari, adult female. Abbreviations as follows: aplt $=$ anal plate; ant $=$ antenna; dmic $=$ dorsal microduct; dset $=$ dorsal setae; edd = enlargement of dorsal derm; $\mathrm{mset}=$ marginal setae; pdp = pregenital disc-pore; prop = preopercular pores; $\mathrm{sp}=\mathrm{simple}$ pore; $\mathrm{spdp}=$ spiracular disc-pore; $\operatorname{stgsp}=$ stigmatic spine; vmic = ventral microduct; vset $=$ ventral setae; vtd = ventral tubular duct.

usually discernible, with trochanter and femur, and tibia and tarsus fused, all segments with few setae; metathoracic legs shortest; total length of all legs: each 150-335 $\mu \mathrm{m}$ long: coxa 78-128 $\mu \mathrm{m}$ long, trochanter + femur 88-110 $\mu \mathrm{m}$ long, tibia + tarsus 118-133 $\mu \mathrm{m}$ long, claw 17.5-22.5 $\mu \mathrm{m}$ long; claws with a small denticle, claw digitules, slender, knobbed; tarsal digitules knobbed or spiniform. Antennae short, each 260$265 \mu \mathrm{m}$ long, 7 segmented, with fleshy setae present on last two antennal segments. Mouthparts missing on specimen.
Etymology. The species is named in homage to Paolo Fontana, entomologist, who collected the insect.

\section{DISCUSSION}

The status of the genus Toumeyella was summarized by Williams \& Kondo (2008), who listed 16 species. Two of them (namely T. cerifera Ferris and T. sonorensis Cockerell $\&$ Parrott) were later transferred to the genus Neotoumeyella 
(Kondo \& Williams 2009). With the description of T. fontanai sp. nov., the number of species in the genus Toumeyella increases to 15 species worldwide and to 5 in Mexico.

The genus Toumeyella has a wide distribution in the New World, with most species being described from the USA, suggesting that many more new species should be found in Mexico and other countries in the Nearctic and Neotropical Regions.

With regard to the host plants, Toumeyella species are mostly oligophagous, usually being recorded off members of one or very few families. The Mexican Toumeyella species have been collected off Fabaceae (T. erythrinae, $T$. mirabilis and T. fontanai), and Pinaceae (T. parvicornis); the host plant of $T$. salle $i$ is unknown.

\section{ACKNOWLEDGEMENTS}

The authors thank Dr. Paolo Fontana (Fondazione Edmund Mach, Consulting and Services Centre - S. Michele all'Adige, Italy) and Patricia Lucero Garcia (Department of Ecology and Natural Resources, UNAM, Mexico City, Mexico), who found the new species during a collecting trip and provided us with the photographs. Dr. Alex Wild kindly provided the photo of $T$. mirabilis which he took during a collecting trip with the first author. Thanks to Dr. David Furth (Smithsonian Institution) for valuable comments regarding Mexican laws concerning the depository of insects collected in Mexico. Thanks also to Dr. Ana Lucia B. G. Peronti for corrections to the Resumo. Many thanks to Dr. Michael L. Williams and Dr. Chris Hodgson for reviewing the manuscript.

\section{REFERENCES}

Ben-Dov, Y.; D. R. Miller \& G. A. P. Gibson. 2010. ScaleNet: a database of the scale insects of the world. Available from: http://www.sel.barc.usda. gov/scalenet/scalenet.htm (accessed July 2010).
Ben-Dov, Y. \& C. J. Hodgson. 1997. Collecting and mounting, p. 389-395. In: Y. Ben-Dov \& C. J. Hodgson (eds.), World Crop Pests. Soft Scale Insects, Their Biology, Natural Enemies and Control. Amsterdam, Elsevier, vol. 7A, 452 p.

Cockerell, T. D. A. 1895. New scale-insects from Arizona. Bulletin Arizona Agricultural Experiment Station 14: 56.

Ferris, G. F. 1921. Report upon a collection of Coccidae from Lower California. Stanford University Publications, Biological Sciences. Palo Alto 1: 61-132.

Ferris, G. F. \& J. B. Kelly. 1923. XIV Expedition of the California Academy of Sciences to the Gulf of California in 1921. Some Coccidae from about the Gulf of California. Proceedings of the California Academy of Sciences 12: 315-318.

Hamon, A. B. \& M. L. Williams. 1984. The soft scale insects of Florida (Homoptera: Coccoidea: Coccidae). Arthropods of Florida and Neighboring Land Areas. Gainesville, Fla. Dept. of Agric. \& Consumer Serv. Div. Plant Ind., 194 p.

Hodgson, C. J. 1994. The scale insect family Coccidae: an identification manual to genera. Wallingford, CAB International, $639 \mathrm{p}$.

Kondo, T. \& M. L. Williams. 2003. A new species of Toumeyella (Hemiptera: Coccoidea: Coccidae) on Erythrina in Mexico. TIP Revista Especializada en Ciencias Químico-Biológicas 6: 11-15.

Kondo, T. \& M. L. Williams. 2004. Redescription of the soft scale insect Toumeyella sallei (Signoret), new combination (Hemiptera: Coccidae: Myzolecaniinae). Annalen Naturhistorischen Museums in Wien 105 B: 211-215.

Kondo, T. \& M. L. Williams. 2009. Redescriptions of Neolecanium leucaenae Ck1l., Toumeyella cerifera Ferris and T. sonorensis Ck1l. \& Parrott and their transfer to Neotoumeyella gen. nov. (Hemiptera: Coccidae), with descriptions of two new species from the Southwestern U.S.A. and Colombia, South America. International Journal of Insect Science 2: 11-27

Signoret, V. 1873. Essai sur les cochenilles ou gallinsectes (Homoptères Coccides), 11e partie. Annales de la Société Entomologique de France (série 5) 3: 395-448.

Williams, M. L. \& T. Kondo. 2008. Status and current composition of the soft scale insect genus Toumeyella (Hemiptera: Coccidae), p. 29-32. In: Branco, M.; Franco, J. C. \& Hodgson, C. J. (Editors), Proceedings of the XI International Symposium on Scale Insect Studies, Oeiras, Portugal, 24-27 September 2007. Lisbon, ISA Press, 322 p.

Williams, M. L. \& M. Kosztarab. 1972. Morphology and systematics of the Coccidae of Virginia with notes on their biology (Homoptera: Coccoidea). Research Division Bulletin, Virginia Polytechnic Institute and State University 74, 215 p. 